\title{
HUBUNGAN PENGETAHUAN GIZI, POLA KONSUMSI DAN RAIHAN NILAI PADA MATAKULIAH ILMU GIZI PANGAN MAHASISWA PRODI TEKNOLOGI PANGAN FAKULTAS TEKNIK UNPAS BANDUNG
}

\author{
Sumartini \\ Hasnelly \\ Program Studi Teknologi Pangan, Fakultas Teknik, Universitas Pasundan \\ J1. Dr. Setiabudhi No. 9,Bandung, 40153, Indonesia \\ E-mail : sumartini@unpas.ac.id
}

\begin{abstract}
Abstrak
Mahasiswa merupakan sumber daya manusia untuk pembangunan di masa mendatang. Untuk meningkatkan kualitas sumber daya manusia banyak faktor yang mempengaruhi. Salah satu faktor penting untuk menjaga kualitas hidup manusia yang optimal adalah kesehatan dan gizi, sedangkan kualitas sumber daya manusia digambarkan melalui pertumbuhan ekonomi, usia, harapan hidup dan tingkat pendidikan. Tujuan dari penelitian ini adalah untuk mengetahui hubungan pengetahuan gizi, pola konsumsi dan raihan nilai pada matakuliah ilmu gizi pangan pada mahasiswa Program Studi Teknologi Pangan FT UNPAS Bandung. Penelitian ini diharapkan dapat meningkatkan pola konsumsi sesuai dengan pengetahuan gizi sehingga siswa dapat memperoleh status gizi ideal dan meningkatkan kesadaran akan kebiasaan makan yang baik di Program Studi Teknologi Pangan FT UNPAS Bandung. Penelitian ini merupakan penelitian cross sectional analitik dengan menggunakan pengetahuan gizi, pola konsumsi dan status gizi sebagai variabel. Total populasi adalah 300 mahasiswa Program Studi Teknologi Pangan FT UNPAS yang mengambil matakuliah ilmu gizi pangan Bandung. Sampel sebanyak 175 siswa ditentukan dengan teknik purposive sampling. Data dikumpulkan dengan menggunakan kuesioner pengetahuan gizi dan Food Frequency Questionnaire (FFQ). Data tabulasi dan analisis data disajikan dalam persentase dan analisis korelasi dengan metode Chi Square. Berdasarkan penelitian menunjukkan: (1) ada hubungan antara pengetahuan gizi dengan status gizi, (2) ada hubungan antara pola konsumsi dengan status gizi, (3) ada hubungan antara pengetahuan gizi dan pola konsumsi dengan status gizi pada mahasiswa (4) ada hubungan antara raihan nilai dengan status gizi, pada mahasiswa Program Studi Teknologi Pangan FT UNPAS dan jajanan yang ada di kampus IV UNPAS sudah memenuhi asupan gizi untuk makanan siang mahasiswa Program Studi Teknologi Pangan FT UNPAS.
\end{abstract}

Kata kunci : Pengetahuan gizi, pola konsumsi, status gizi, prestasi.

\section{Pendahuluan}

Gizi merupakan faktor yang terpenting dalam indikator kesehatan pada manusia. Gizi yang tidak seimbang baik kekurangan maupun kelebihan gizi akan menurunkan kualitas sumber daya manusia. Mahasiswa usia remaja merupakan periode rentan gizi disebabkan oleh beberapa hal, yaitu kebutuhan zat gizi meningkat pada usia $17-19$ tahun sebesar 2675 kkal untuk lakilaki dan $2125 \mathrm{kkal}$ untuk perempuan, dari perubahan gaya hidup dan aktivitas fisik remaja itu sendiri. Remaja memerlukan zat gizi yang lebih tinggi karena peningkatan pertumbuhan fisik dan perkembangan tubuh yang signifikan (Depkes, 2014).

Berdasarkan RISKESDAS (2013), prevalensi gizi kurus menurut Indeks Massa Tubuh (IMT) pada remaja adalah $13,1 \%$ pada laki-laki dan $5,7 \%$ pada perempuan dan prevalensi gizi lebih pada laki-laki $6.6 \%$ dan perempuan $8,1 \%$. Remaja di Indonesia terjadi peningkatan status gizi sangat kurus dan kurus. Namun prevalensi pada status gizi gemuk memiliki hasil yang berbeda signifikan dibandingkan dengan status gizi sangat kurus dan kurus. Pada tahun 2010 prevalensi gizi gemuk adalah $1.4 \%$ dan meningkat pada tahun 2013 menjadi 7,3\% (RISKESDAS, 2013).

Faktor-faktor yang dapat mempengaruhi status gizi secara langsung antara lain pola konsumsi makanan sehari-hari, aktivitas fisik, dan keadaan kesehatan. Pola konsumsi pangan umumnya dipengaruhi oleh faktor sosial budaya, demografi, dan faktor gaya hidup, serta berkaitan dengan risiko beberapa penyakit degeneratif.

Pengetahuan kognitif merupakan faktor yang sangat penting untuk terbentuknya tindakan seseorang. Pengetahuan yang didasari dengan pemahaman yang tepat akan menumbuhkan perilaku yang diharapkan, khususnya tentang pengetahuan gizi. Jika pengetahuan remaja kurang tentang gizi, maka upaya yang dilakukan remaja untuk menjaga keseimbangan makanan yang dikonsumsi dengan yang dibutuhkan akan berkurang dan menyebabkan masalah gizi kurang atau gizi lebih (Notoatmodjo, 2003). 
Ketua Umum Pergizi Pangan Indonesia, Profesor Hardinsyah, mengemukakan baik masyarakat mampu maupun tidak mampu di Indonesia memiliki pengetahuan tentang gizi seimbang yang masih kurang. Sehingga saat pemenuhan gizi seimbang tak tercapai, masyarakat yang mampu juga bisa mengalami kekurangan ataupun kelebihan gizi (Windhi, 2016). Hal ini mengindikasikan bahwa tingkat pengetahuan gizi pada remaja di Indonesia masih tergolong rendah sehingga sikap mereka terhadap pemilihan makanan yang bergizi masih kurang.

Keadaan gizi yang mengkhawatirkan dapat terjadi pada mahasiswa. Terjadinya permasalahan ini harus mendapat penanganan yang serius. Salah satu upaya yang dapat dilakukan adalah melalui pendidikan gizi yaitu tentang gizi seimbang.

Pengetahuan kognitif merupakan faktor yang sangat penting untuk terbentuknya tindakan seseorang. Pengetahuan yang didasari dengan pemahaman yang tepat akan menumbuhkan perilaku yang diharapkan, khususnya tentang pengetahuan gizi. Pengetahuan remaja tentang pengetahuan gizi adalah pemahaman seseorang tentang ilmu gizi, zat gizi, serta interaksi antara zat gizi terhadap status gizi dan kesehatan. Jika pengetahuan remaja kurang tentang gizi, maka upaya yang dilakukan remaja untuk menjaga keseimbangan makanan yang dikonsumsi dengan yang dibutuhkan akan berkurang dan menyebabkan masalah gizi kurang atau gizi lebih (Notoatmodjo, 2003).

\section{Bahan, Alat dan Metode Penelitian}

\section{Bahan-bahan Penelitian}

Dalam penelitian ini bahan yang digunakan adalah sampel dari mahasiswa Program Studi Teknologi Pangan FT UNPAS yang berusia 19 tahun.

\section{Alat-alat Penelitian}

Dalam penelitian ini alat yang digunakan untuk penelitian adalah data yang diperoleh dari sampel mahasiswa melalui wawancara dan kuesioner yang berisi sejumlah pertanyaan. Kuesioner yang digunakan berupa pernyataan dengan pilihan tertutup dimana responden hanya memberikan check list pada kolom yang tersedia.

\section{Metodologi Penelitian}

Jenis penelitian yang di gunakan dalam penelitian ini adalah metode penelitian survei yang bersifat analitik, yaitu suatu metode penelitian yang mencoba menggali bagaimana dan mengapa fenomena itu terjadi (Notoatmodjo, 2005).

Pendekatan yang digunakan adalah cross sectional, yaitu suatu penelitian yang mendesain pengumpulan datanya dilakukan pada satu titik waktu (at one point in time): fenomena yang diteliti adalah selama satu periode pengumpulan data (Swarjana, 2012).

\section{Prosedur Penelitian}

Penelitian dilakukan dalam beberapa langkah yaitu:

1. Pembuatan Kuesioner

Teknik pengumpulan data dalam penelitian ini menggunakan kuesioner tentang hubungan pengetahuan gizi dan pola konsumsi terhadap status gizi pada mahasiswa Program Studi Teknologi Pangan FT UNPAS Bandung.

2. Penentuan Pertanyaan

Didasarkan pada pernyataan Supranto (2001), yang menyatakan bahwa jumlah pertanyaan yang baik dapat ditentukan dengan cara, jumlah sampel dalam penelitian dibagi 6 (enam). Dalam penelitian ini menggunakan jumlah sampel sebanyak 79 responden maka jumlah minimal pertanyaan dalam kuesioner adalah 13 (tiga belas) pertanyaan.

3. Survey Lokasi

Tahap ini meliputi survey jumlah mahasiswa Program Studi Teknologi Pangan FT UNPAS Bandung usia 19 tahun.

4. Penentuan Jumlah Sampel

Peneliti menentukan jumlah sampel dalam penelitian dengan menggunakan rumus estimasi proporsi dengan tingkat ketelitian yang diinginkan sebesar $5 \%$.

5. Penyebaran Kuesioner

Setelah kuesioner dibuat, maka peneliti akan menyebarkan kuesioner ke sejumlah sampel. Dimana sebelum memulai penelitian, peneliti memperkenalkan dahulu dan memberi tahu kepada responden mengenai maksud dan tujuan penelitian serta memberikan surat pernyataan kesediaan menjadi responden (inform consent). Setelah responden bersedia, maka responden diberi pertunjuk oleh peneliti tentang tata cara untuk mengisi kuesioner.

6. Pengolahan Data

Pada penelitian ini pengolahan data dilakukan melalui beberapa tahapan meliputi editing, coding, entry dan cleaning yang dilakukan sebelum melakukan analisis data. Data yang diperoleh akan ditabulasi ke dalam tabel menurut jenis kuesioner yang sudah diisi.

7. Analisis Data

Setelah data diolah maka selanjutnya data akan dianalisis. Data dianalisis untuk dilihat distribusi frekuensi dengan ukuran persentase atau proporsi. Kemudian data tersebut diuji untuk mengetahui apakah ada hubungan antara pengetahuan gizi dan pola konsumsi terhadap status gizi.

\section{Hasil dan pembahasan \\ Penentuan Jumlah Populasi}

Populasi adalah sasaran penelitian yang memiliki karakteristik tertentu yaitu sesuai dengan jenis penelitian berdasarkan hasil observasi yang dilakukan oleh peneliti didapatkan bahwa yang menjadi objek 
penelitian adalah seluruh mahasiswa Program Studi Teknologi Pangan yang mengambil matakuliah Ilmu Gizi di Semester Genap tahun ajaran 2017/2018 berjumlah 224 mahasiswa dengan dasar pertimbangan termasuk ke dalam rentang usia remaja dimana biasanya merupakan periode rentan gizi.

\section{Penentuan Jumlah Sampel}

Teknik pengambilan sampel dalam penelitian ini, menggunakan menggunakan rumus estimasi proporsi dengan rumus sebagai berikut :

$$
n=\frac{N}{1+N e^{2}}
$$

Keterangan:

$\mathrm{n}$ = Besar sampel

$\mathrm{N}=$ Besar populasi

e = Tingkat keakuratan yang diinginkan

$n=\frac{224}{1+2,24}$

$n=\frac{224}{3,24}$

$\mathrm{n}=69,14$ mahasiswa $\infty 70$ mahasiswa

\section{Uji Validitas dan Reliabilitas}

Uji validitas untuk mengukur sejauh mana relevansi pertanyaan terhadap apa yang ditanyakan atau apa yang ingin diukur dalam penelitian. Untuk penentuan tingkat korelan dari tiap item atau butir soal yang diperoleh harus membandingkan dengan angka tabel korelasi nilai r. Kriteria validitas tiap item untuk 30 responden adalah: jika $(r)>0,30$ maka item dinyatakan valid, sedangkan jika $(r)<0,30$ maka item tidak valid (Sufren, 2014).

Uji validitas dapat dihitung menggunakan rumus berikut :

$$
r_{p b i s}=\frac{M_{p}-M_{t}}{S_{t}} \sqrt{\frac{p}{q}}
$$

Keterangan:

rpbis = koefisien korelasi poin biserial

$\mathrm{Mp}=$ rerata skor yang menjawab benar

$\mathrm{Mt} \quad=$ rata-rata skor total

St $\quad=$ standar deviasi total

$\mathrm{p} \quad=$ proporsi jawaban benar

$\mathrm{q}=$ proporsi jawaban salah $(1-\mathrm{p})$

$\mathrm{r}_{\mathrm{pbis}}=\sqrt{\frac{M p-M t}{S t}}-\frac{p}{q}=\sqrt{\frac{14,8-13,7}{133_{4}}}\left(\frac{0,9}{0,1}\right)=0,85$

Uji validitas telah dilaksanakan pada tanggal 24 Maret 2018. Uji validitas dilakukan pada 70 mahasiswa Program Studi Teknologi Pangan dan didapat dari 20 item pertanyaan yang bertujuan untuk mengetahui pengetahuan gizi dinyatakan valid. Maka pertanyaan tersebut relevan terhadap apa yang akan diukur dalam penelitian.

Uji reliabilitas untuk mengukur sejauh mana suatu alat pengukur dapat dipercaya atau diandalkan digunakan koefisien reabilitas. Sekumpulan pertanyaan untuk mengukur suatu variabel dikatakan reliable dan berhasil mengukur variabel yang kita ukur jika koefisien reliabilitasnya $\geq 0,700$ (Sufren, 2014).

Uji reliabilitas dapat dihitung menggunakan rumus berikut:

$$
r=\left(\frac{n}{n-1}\right)\left(\frac{S^{2}-\Sigma p q}{S^{2}}\right)
$$

Keterangan:

$\mathrm{p}=$ proporsi jawaban benar

$\mathrm{q}=$ proporsi jawaban salah $(1-\mathrm{p})$

$\mathrm{n}=$ jumlah responden

$\mathrm{S}=$ nilai varians

$r=\left(\frac{n}{n-1}\right)\left(\frac{s^{2}-\Sigma p q}{s^{2}}\right)$

$r=\left(\frac{70}{70-1}\right)\left(\frac{3.51^{2}-0.85}{3.51^{2}}\right)$

$=0,94$

Pada penelitian ini pertanyaan mengenai pengetahuan gizi yang reliabel yaitu sebanyak 20 item pertanyaan dengan koefisien reabilitas 0,94. Maka pertanyaan tersebut dapat dipercaya untuk digunakan sebagai alat ukur. Menurut Arikunto (2010), semakin tinggi nilai koefisien reabilitas maka semakin tinggi tingkat kepercayaan alat tersebut digunakan sebagai instrumen penelitian.

\section{Hasil Observasi dan Wawancara}

Pemilihan lokasi di Tek.Pangan dilatarbelakangi oleh data hasil studi pra pendahuluan yang dilakukan oleh peneliti pada tanggal 27 Maret 2018. Dari mahasiswa yang lagi belajar mata kuliah ilmu gizi didapat ada mahasiswa yang memiliki status gizi berdasarkan Indeks Massa Tubuh (IMT). ada sekitar 5 orang status gizi kurang dan juga yang mengalami obesitas ada 3 orang dari hasil tersebut maka peneliti tertarik untuk meneliti hubungan status gizi terhadap pola konsumsi,pengetahuan gizi dan raihan nilai.

\section{Gambaran Usia Mahasiswa Teknologi Pangan}

Berdasarkan hasil penelitian diperoleh data mengenai usia responden $19-22$ tahun, yang dilakukan penelitian adalah usia 19 tahun,karena usia tersebut merupakan batasan maksimum usia remaja. 
Tabel 1. Gambaran Tingkat Pengetahuan Responden Mahasiswa Teknologi Pangan

\begin{tabular}{|c|c|c|c|c|}
\hline \multirow{2}{*}{$\begin{array}{c}\text { Tingkat } \\
\text { Pengetahuan }\end{array}$} & \multicolumn{4}{|c|}{ Jenis Kelamin } \\
\cline { 2 - 5 } & \multicolumn{2}{|c|}{ Laki-laki } & \multicolumn{2}{c|}{ Perempuan } \\
\cline { 2 - 5 } & Jumlah & $\%$ & Jumlah & \% \\
\hline Baik & 2 & 13 & 13 & 24 \\
\hline Cukup & 7 & 47 & 30 & 55 \\
\hline Kurang & 6 & 40 & 12 & 21 \\
\hline Total & 15 & 100 & 55 & 100 \\
\hline
\end{tabular}

Tabel 2. Gambaran Pola Konsumsi Responden Mahasiswa Teknologi Pangan

\begin{tabular}{|c|c|c|c|c|}
\hline \multirow{2}{*}{$\begin{array}{c}\text { Pola } \\
\text { Konsumsi }\end{array}$} & \multicolumn{3}{|c|}{ Jenis Kelamin } \\
\cline { 2 - 5 } & \multicolumn{2}{|c|}{ Laki-laki } & \multicolumn{2}{c|}{ Perempuan } \\
\cline { 2 - 5 } & Jumlah & $\%$ & Jumlah & $\%$ \\
\hline Baik & 4 & 27 & 10 & 18 \\
\hline Cukup & 1 & 7 & 12 & 22 \\
\hline Kurang & 10 & 66 & 33 & 60 \\
\hline Total & 15 & 100 & 55 & 100 \\
\hline
\end{tabular}

Tabel 3. Gambaran Raihan Nilai Responden Mahasiswa Teknologi Pangan

\begin{tabular}{|c|c|c|c|c|}
\hline \multirow{2}{*}{ Raihan Nilai } & \multicolumn{4}{|c|}{ Jenis Kelamin } \\
\cline { 2 - 5 } & \multicolumn{2}{|c|}{ Laki-laki } & \multicolumn{2}{c|}{ Perempuan } \\
\cline { 2 - 5 } & Jumlah & \% & Jumlah & \% \\
\hline Sangat Baik & 8 & 53 & 43 & 78 \\
\hline Baik & 2 & 14 & 10 & 18 \\
\hline Cukup & 5 & 33 & 2 & 14 \\
\hline Total & 15 & 100 & 55 & 100 \\
\hline
\end{tabular}

Tabel 4. Gambaran Status Gizi Responden Mahasiswa Teknologi Pangan

\begin{tabular}{|c|c|c|c|c|}
\hline \multirow{2}{*}{ Status Gizi } & \multicolumn{4}{|c|}{ Jenis Kelamin } \\
\cline { 2 - 5 } & \multicolumn{2}{|c|}{ Laki-laki } & \multicolumn{2}{c|}{ Perempuan } \\
\cline { 2 - 5 } & Jumlah & \% & Jumlah & \% \\
\hline Kurus Berat & 0 & 0 & 3 & 5 \\
\hline Kurus Ringan & 3 & 20 & 11 & 20 \\
\hline Normal & 11 & 73 & 35 & 65 \\
\hline Gemuk Ringan & 0 & 0 & 3 & 5 \\
\hline Gemuk Berat & 1 & 7 & 3 & 5 \\
\hline Total & 15 & 100 & 55 & 100 \\
\hline
\end{tabular}

Berdasarkan tabel diatas diperoleh mayoritas jenis kelamin mahasiswa terbanyak adalah perempuan yaitu sebanyak 55 responden $(78,6 \%)$, sedangkan laki-laki sebanyak 15 responden $(21,4 \%)$

Jenis kelamin perempuan menempati persentase terbanyak dikarenakan banyak siswa yang beranggapan bahwa program studi teknologi pangan sama dengan tataboga.

Dalam hal pengetahuan gizi makanan yang cukup menguasai adalah perempuan (55\%), sedangkan lakilaki kurang menguasai (40\%), dalam hal kosumsi makanan laki-laki lebih baik (27\%) dan kurang baik $(66 \%)$. Dalam hal raihan nilai yang sangat baik adalah perempuan sedangkan laki-laki banyak nilai kurangnya. Status gizi berdasarkan nilai IMT mahasiswa perempuan kekurangan gizi (5\%) dan yang termasuk obesitas sekitar 5\%.

\section{Gambaran Pengetahuan Gizi Mahasiswa Teknologi Pangan FT UNPAS}

Tabel 5. Gambaran Pengetahuan Gizi Mahasiswa Teknologi Pangan FT UNPAS

\begin{tabular}{|c|c|c|}
\hline $\begin{array}{c}\text { Tingkat } \\
\text { Pengetahuan }\end{array}$ & Frekuensi & Persentase (\%) \\
\hline Baik & 15 & 21 \\
\hline Cukup & 37 & 53 \\
\hline Kurang & 18 & 26 \\
\hline Jumlah & $\mathbf{7 0}$ & $\mathbf{1 0 0 . 0 0}$ \\
\hline
\end{tabular}

Berdasarkan Tabel 5 diperoleh data sebanyak 37 responden $(53 \%)$ memiliki kategori pengetahuan yang cukup, kemudian sebanyak 18 responden (26\%) terkategorikan pengetahuan kurang, dan 15 responden (21\%) memiliki kategori baik.

Menurut peneliti ada beberapa sebab yang membuat proporsi responden yang terkategorikan baik menempati urutan terendah. Hal ini disebabkan oleh kurangnya informasi yang didapat oleh responden baik secara formal maupun non formal.

\section{Gambaran Pola Konsumsi Mahasiswa Teknologi Pangan FT UNPAS}

Tabel 6. Gambaran Pola Konsumsi Mahasiswa Teknologi Pangan FT UNPAS

\begin{tabular}{|c|c|c|}
\hline $\begin{array}{c}\text { Pola } \\
\text { Konsumsi }\end{array}$ & Frekuensi & Persentase (\%) \\
\hline Baik & 14 & 20 \\
\hline Cukup & 13 & 19 \\
\hline Kurang & 43 & 61 \\
\hline Jumlah & 70 & 100 \\
\hline
\end{tabular}

Berdasarkan Tabel 6 diperoleh data sebanyak 14 responden $(20 \%)$ memiliki pola konsumsi yang baik, kemudian sebanyak 13 responden (19\%) memiliki pola konsumsi yang cukup, dan sebesar 43 responden (61\%) memiliki pola konsumsi yang kurang

Pola makan merupakan cara makan baik di rumah maupun di luar rumah yang meliputi frekuensi dan waktu makan, jenis dan jumlah makanan yang dikonsumsi, termasuk makanan yang disukai dan makanan pantangan. Dari data penelitian dapat disimpulkan bahwa pola konsumsi pada mahasiswa Teknologi Pangan kurang baik. Hal ini biarpun sudah ditunjang dengan kemudahan mahasiswa dalam mendapatkan makanan sehat seperti di kantin atau membawa bekal dari rumah ketika sedang mengikuti perkuliahan. Padahal ketika mahasiswa tidak ada perkuliahan, makanan dengan gizi seimbang dapat mudah diperoleh di tempat tinggal atau jika tidak dapat diperoleh dari lingkungan sekitar tempat tinggal.

Berdasarkan hasil data Food Frequency Questionnaire dapat diambil kesimpulan jenis makanan yang paling sering dikonsumsi adalah nasi pada jenis karbohidrat, ayam pada jenis protein 
hewani, tempe pada jenis protein nabati, bayam pada sayuran, dan pisang pada buah. Jenis makanan tersebut baik untuk dikonsumsi dalam jumlah yang seimbang. Pemilihan jenis makanan tersebut dilatarbelakangi oleh kemudahan dalam memperoleh makanan dan harga yang terjangkau menurut beberapa mahasiswa Teknologi Pangan FT UNPAS.

Suplemen vitamin dan mineral tidak dimasukkan ke dalam daftar kuesioner dikarenakan suplemen merupakan makanan pelengkap yang tidak diwajibkan untuk dikonsumsi setiap hari. Suplemen perlu dikonsumsi pada saat kondisi tubuh kekurangan asupan vitamin dan mineral.

\section{Gambaran Raihan Nilai Mahasiswa Teknologi Pangan FT UNPAS}

Tabel 7. Gambaran Raihan Nilai Mahasiswa Teknologi Pangan FT UNPAS

\begin{tabular}{|c|c|c|}
\hline $\begin{array}{c}\text { Raihan } \\
\text { Nilai }\end{array}$ & Frekuensi & Persentase (\%) \\
\hline Sangat Baik & 51 & 73 \\
\hline Baik & 13 & 18 \\
\hline Cukup & 6 & 9 \\
\hline Jumlah & 70 & 100 \\
\hline
\end{tabular}

Dalam hal raihan nilai untuk mahasiswa teknologi Pangan FT UNPAS sudah baik ditunjukkan ari hasil quisioner ternya sebanyak $73 \%$ meraih nilai sangat baik dan ditunjukkan juga dengan tidak adanya mahasiswa yang tidak lulus dalam matakuliah Ilmu Gizi Pangan.

\section{Gambaran Status Gizi Mahasiswa Teknologi Pangan FT UNPAS}

Tabel 8. Gambaran Status Gizi Mahasiswa Teknologi Pangan FT UNPAS

\begin{tabular}{|c|c|c|}
\hline Status Gizi & Frekuensi & Persentase (\%) \\
\hline Kurus Berat & 3 & 5 \\
\hline Kurus Ringan & 14 & 20 \\
\hline Normal & 46 & 66 \\
\hline Gemuk Ringan & 3 & 4 \\
\hline Gemuk Berat & 4 & 6 \\
\hline Kurus Berat & 70 & 100 \\
\hline
\end{tabular}

Berdasarkan Tabel 8. diperoleh data sebanyak 46 responden $(66 \%)$ memiliki status gizi normal, kemudian sebanyak 14 responden (20\%) memiliki status gizi kurus tingkat ringan, sebanyak 3 responden (5\%) memiliki status gizi kurus tingkat ringan dan 3 responden $(4 \%)$ memiliki status gizi gemuk tingkat ringan, 4 responden $(6 \%)$ memiliki status gizi gemuk tingkat berat.

Hasil penelitian menunjukkan mayoritas mahasiswa Teknologi Pangan memiliki status gizi normal dengan persentase $66 \%$. Namun masih ada mahasiswa yang memiliki status gizi kurang $20 \%$ dan status gizi lebih $10 \%$.
Faktor yang menyebabkan masih adanya mahasiswa dengan kategori status gizi kurang mungkin dikarenakan jumlah asupan zat gizi yang tidak cukup. Hal ini bisa dikarenakan pola diet ketat pada remaja putri atau lebih sering mengonsumsi cemilan dibanding makanan pokok sehingga asupan nutrisinya tidak terpenuhi.

Sedangkan faktor yang menyebabkan mahasiswa dengan status gizi lebih dikarenakan terlalu banyak mengkonsumsi karbohidrat, lemak maupun protein, juga karena kurang bergerak. Pola makan merupakan faktor resiko dari kejadian obesitas pada remaja dimana remaja yang memiliki pola makan berlebih mempunyai resiko berat badan lebih dan begitu sebaliknya dengan remaja yang memiliki pola makan kurang dari kebutuhan tubuhnya (WKNPG, 1998).

\section{Hubungan Pengetahuan Gizi dengan Status Gizi Mahasiswa Teknologi Pangan FT UNPAS}

Analisis korelasi dilakukan untuk mengetahui hubungan antar variabel yang diteliti yaitu pengetahuan gizi sebagai variabel independen dan status gizi sebagai variabel dependen dengan menggunakan uji Chi Square. Diperoleh nilai hitung $=1,074>0,207$ yang berarti ada hubungan yang bermakna antara pengetahuan gizi dengan status gizi. Hubungan antara pengetahuan dengan status gizi terlihat bahwa semakin rendah pengetahuan mahasiswa tentang gizi akan semakin besar kemungkinan untuk memiliki status gizi kurus atau gemuk.

Menurut Baron (2004), sikap tumbuh diawali dari pengetahuan yang dipersepsikan sebagai suatu hal yang baik maupun yang tidak baik, kemudian diinternalisasikan ke dalam dirinya. Hal ini dapat diartikan bahwa sikap yang baik dan kurang terbentuk dari komponen pengetahuan dan hal ini akan mempengaruhi perilaku seseorang dalam hal ini adalah pemilihan makanan yang seimbang.

Pengetahuan gizi sangat penting dalam menentukan perilaku seseorang dalam menentukan jenis makanan yang dipilih. Semakin baik pengetahuan gizi seseorang maka semakin baik pula dalam menentukan jenis dan jumlah makanan yang diperlukan bagi tubuh. Jika kebutuhan nutrisinya terpenuhi maka kecenderungan seseorang untuk mendapatkan status gizi yang baik akan semakin tinggi.

Hal ini berkaitan dengan teori yang mengatakan bahwa tingkat pengetahuan gizi seseorang berpengaruh terhadap sikap dan perilaku dalam memilih makanan yang menentukan mudah tidaknya seseorang memahami manfaat kandungan gizi dari makanan yang dikonsumsi (Sediaoetama, 2000).

Selanjutnya, Sediaoetama (2000) berpendapat bahwa kesalahan dalam memilih makanan dan kurang cukupnya pengetahuan tentang gizi akan mengakibatkan timbulnya masalah gizi yang akhirnya mempengaruhi status gizi. Status gizi yang baik hanya 
dapat tercapai dengan pola makan yang baik, yaitu pola makan yang didasarkan atas prinsip menu seimbang, alami, dan sehat.

\section{Hubungan Pola Konsumsi dengan Status Gizi Mahasiswa Teknologi Pangan}

Analisis ini menggunakan pola konsumsi sebagai variabel independen dan status gizi sebagai variabel dependen untuk diuji korelasi dengan menggunakan uji Chi Square. Diperoleh nilai hitung $=533,78>0 \mathrm{~m} 207$ yang berarti ada hubungan yang bermakna antara pola konsumsi dengan status gizi. Hubungan antara pola konsumsi dengan status gizi terlihat bahwa semakin kurang baik pola konsumsi mahasiswa maka semakin besar kemungkinan untuk memiliki status gizi kurus. Dari 70 mahasiswa yang memiliki pola konsumsi baik yang memiliki status gizi normal sebanyak 45 responden, status gizi gemuk berat sebanyak 2 responden, status gizi gemuk ringan sebesar 0 responden.

Pada dasarnya status gizi seseorang ditentukan berdasarkan konsumsi gizi dan kemampuan tubuh dalam menggunakan zat-zat gizi tersebut. Pola makan remaja sangat dipengaruhi oleh lingkungan sekitar. Remaja lebih menyukai makanan dengan kandungan natrium dan lemak yang tinggi tetapi rendah vitamin dan mineral. Berdasarkan hasil wawancara dengan beberapa responden dengan status gizi lebih dan status gizi kurang, didapat hasil responden lebih menyukai makanan cemilan (makanan padat kalori) dan fast food dibanding dengan makanan pokok yang seimbang dan dianjurkan untuk dikonsumsi sehari-hari. Sehingga rasa suka yang berlebihan terhadap makanan tertentu menyebabkan kebutuhan gizi tidak terpenuhi dengan optimal.

Kebiasaan makan yang sering terlihat pada remaja antara lain makan cemilan, melewatkan waktu makan terutama sarapan pagi, waktu makan tidak teratur, sering makan fast food, jarang mengkonsumsi sayur, buah dan ataupun produk peternakan (dairy food) serta pengontrolan berat badan yang salah pada remaja putri. Hal tersebut dapat mengakibatkan asupan makanan tidak sesuai kebutuhan dan gizi seimbang dengan akibatnya gizi kurang atau lebih (Irianto, 2014).

\section{Raihan Nilai dengan Status Gizi Mahasiswa Teknologi Pangan FT UNPAS}

Raihan nilai di prodi Teknologi Pangan pada umumnya sangat baik ditunjang dengan hasil penelitian ada $73 \%$ mahasiswa meraih nilai sangat baik dan tidak ada mahasiswa yang tidak lulus, sedangkan yang meraih nilai cukup hanya $9 \%$.

\section{Hubungan Pengetahuan Gizi dan Pola Konsumsi dengan Status Gizi Mahasiswa Teknologi Pangan}

Diperoleh nilai $\mathrm{R}=0.94$ untuk korelasi ganda pengetahuan gizi dan pola konsumsi terhadap status gizi, artinya menunjukkan bahwa pengetahuan gizi dan pola konsumsi memiliki hubungan yang kuat terhadap status gizi.

Pengetahuan gizi merupakan aspek kognitif yang menunjukkan pemahaman responden tentang ilmu gizi, jenis zat gizi, serta interaksinya terhadap status gizi. Pengetahuan gizi merupakan landasan yang penting dalam menentukan konsumsi makanan (Khomsan, 2000). Menurut Irawati (1992), tingkat pengetahuan gizi seseorang berpengaruh terhadap sikap dan perilaku dalam pemilihan makanan yang pada akhirnya akan berpengaruh pada keadaan gizi individu yang bersangkutan. Semakin tinggi tingkat pengetahuan gizi seseorang diharapkan semakin baik pula keadaan gizinya. Akan tetapi, pengetahuan gizi yang dimiliki seseorang belum tentu dapat mengubah kebiasaan makannya, dimana mereka memiliki pemahaman terkait asupan nutrisi yang diperlukan oleh tubuh tetapi tidak mengaplikasikan pengetahuan gizi tersebut dalam kehidupan sehari-harinya.

Pengetahuan gizi merupakan aspek kognitif yang menunjukkan pemahaman responden tentang ilmu gizi, jenis zat gizi, serta interaksinya terhadap status gizi. Pengetahuan gizi merupakan landasan yang penting dalam menentukan konsumsi makanan (Khomsan, 2000). Menurut Irawati (1992), tingkat pengetahuan gizi seseorang berpengaruh terhadap sikap dan perilaku dalam pemilihan makanan yang pada akhirnya akan berpengaruh pada keadaan gizi individu yang bersangkutan. Semakin tinggi tingkat pengetahuan gizi seseorang diharapkan semakin baik pula keadaan gizinya. Akan tetapi, pengetahuan gizi yang dimiliki seseorang belum tentu dapat mengubah kebiasaan makannya, dimana mereka memiliki pemahaman terkait asupan nutrisi yang diperlukan oleh tubuh tetapi tidak mengaplikasikan pengetahuan gizi tersebut dalam kehidup sehari-harinya.

Menurut Supariasa (2014), status gizi dipengaruhi secara langsung oleh tingkat konsumsi energi yang diperoleh dari karbohidrat, protein, dan lemak. Energi diperlukan untuk pertumbuhan, metabolisme, utilisasi bahan makanan dan aktivitas. Kebutuhan energi terutama dibentuk oleh karbohidrat dan lemak, sedangkan protein untuk menyediakan asam amino bagi sintesis protein sel dan hormon serta enzim untuk mengukur metabolisme.

Makanan diperlukan oleh manusia untuk menunjang pertumbuhan, mempertahankan hidup, dan melakukan aktivitas fisik. Apabila konsumsi makanan kurang dari kebutuhan tubuh maka cadangan makanan yang terdapat di dalam tubuh yang disimpan dalam otot dan lemak akan digunakan. Kekurangan asupan ini apabila berlangsung dalam jangka waktu yang cukup lama maka akan mengakibatkan menurunnya berat badan dan kekurangan zat gizi lain. Penurunan berat badan yang berlanjut akan menyebabkan kedaan gizi kurang yang akan berakibat terhambatnya proses pertumbuhan dan perkembangan. Dampak lain yang dapat timbul seseorang mudah terjangkit penyakit 
menular serta penurunan prestasi akademik. Sedangkan konsumsi makanan secara berlebih dapat mengakibatkan kenaikan berat badan dan apabila terus berlanjut maka akan menyebabkan kegemukan dan resiko penyakit degeneratif.

Pada penelitian ini mahasiswa dengan kategori kurus didominasi oleh mahasiswa perempuan dengan persentase $79 \%$. Hal ini disebabkan adanya persepsi bahwa untuk meningkatkan perhatian terhadap bentuk tubuhnya, penampilan fisik dengan tubuh kurus adalah yang paling digemari. Remaja putri biasanya lebih mementingkan penampilan, mereka tidak ingin menjadi gemuk sehingga membatasi diri dengan memilih makanan yang tidak mengandung banyak energi dan tidak mau makan pagi. Berdasarkan penelitian-penelitian sebelumnya, remaja putri lebih mudah terpengaruh untuk melakukan praktik penurunan berat badan yang tidak sehat yang berujung pada penurunan status gizi (Marita, 2001).

Pada dasarnya sangat penting bagi individu untuk mempertahankan berat badan ideal karena dengan berat badan yang ideal, status kesehatan akan optimal. Pemantauan berat badan secara berkala akan menjadi tindakan pencegahan terhadap obesitas maupun KEK (Kekurangan Energi Kronis). Namun perlu diperhatikan cara pengontrolan berat badan, pola konsumsi yang benar dan sehat, yang menunjang status gizi yang ideal (Nurhaedar, 2012). Seiring dengan meningkatnya populasi remaja di Indonesia, masalah gizi remaja perlu mendapatkan perhatian khusus karena berpengaruh terhadap pertumbuhan dan perkembangan tubuh serta dampaknya pada masalah gizi dewasa. Gizi yang baik akan menghasilkan sumber daya manusia yang berkualitas, sehat, cerdas, dan produktif.

\section{Hasil nanalisis Nilai Gizi dan Angka Kecukupan Gizi (AKG) Pada Makanan Yang dijual di Kantin UNPAS Jalan Setiabudi No 193 Bandung}

Tabel 9. Hasil Analisis Nilai Gizi per 100 gram Pada

Makanan Yang Ada Di Kantin Kampus IV UNPAS Bandung Periode Bulan September 2018

\begin{tabular}{|c|c|c|c|}
\hline No & Nama Makanan & Berat & $\begin{array}{c}\text { Kalori } \\
(\mathrm{kkal})\end{array}$ \\
\hline 1 & $\begin{array}{c}\text { Goreng Ayam } \\
\text { (Dada) }\end{array}$ & $100 \mathrm{~g}$ & 264,47 \\
\hline 2 & Chiken Katsu & $100 \mathrm{~g}$ & 341,75 \\
\hline 3 & Batagor (Tahu) & $100 \mathrm{~g}$ & 347,28 \\
\hline 4 & Batagor (Siomay) & $100 \mathrm{~g}$ & 359,73 \\
\hline 5 & Baso Sapi (besar) & $100 \mathrm{~g}$ & 279,44 \\
\hline 6 & Mie Ayam & $100 \mathrm{~g}$ & 259,21 \\
\hline 7 & Nasi Goreng & $100 \mathrm{~g}$ & 353,74 \\
\hline 8 & Jus Mangga Kweni & $100 \mathrm{~g}$ & 66,4 \\
\hline 9 & Nasi Timbel Putih & $100 \mathrm{~g}$ & 138,84 \\
\hline 10 & Cilok Goreng & $100 \mathrm{~g}$ & 259,21 \\
\hline 11 & Tahu goreng & $100 \mathrm{~g}$ & 252,63 \\
\hline 12 & Tempe goreng & $100 \mathrm{~g}$ & 370,47 \\
\hline
\end{tabular}

Tabek 10. Hasil Analisis Nilai Gizi dan Nilai Angka Kecukupan Gizi (AKG) pada Satu Porsi Makanan Kantin Kampus IV UNPAS Bandung Periode Bulan September 2018

\begin{tabular}{|c|c|c|c|}
\hline No & Nama Makanan & Berat & $\%$ AKG \\
\hline 1 & $\begin{array}{c}\text { Goreng Ayam } \\
\text { (Dada) }\end{array}$ & 55 gram & 6,77 \\
\hline 2 & Chiken Katsu & 56 gram & 8,90 \\
\hline 3 & Batagor (Tahu) & 20 gram & 3,23 \\
\hline 4 & Batagor (Siomay) & 19 gram & 3,18 \\
\hline 5 & Baso Sapi (besar) & 46 gram & 5,98 \\
\hline 6 & Mie Ayam & 300 gram & 36,17 \\
\hline 7 & Nasi Goreng & 320 gram & 52,65 \\
\hline 8 & Jus Mangga Kweni & 390 gram & 12,05 \\
\hline 9 & Nasi Timbel Putih & 200 gram & 12,92 \\
\hline 10 & Cilok Goreng & 15 gram & 1,81 \\
\hline 11 & Tahu goreng & 37 gram & 4,35 \\
\hline 12 & Tempe goreng & 27 gram & 4,65 \\
\hline 13 & Sayur Kangkung & 157 gram & 11,08 \\
\hline 14 & Sayur Taoge & 120 gram & 6,47 \\
\hline
\end{tabular}

Catatan: Perhitungan AKG distandarkan pada acuan label pangan tahun 2016 : $2150 \mathrm{kkal}$

Contoh perhitungan untuk mahasiswa perempuan dan laki-laki umur 19 tahun adalah

Jika mengkonsumsi nasi timbel putih, goreng ayam, tahu dan tempe jumlah kalori yang didapatkan pada makan siang

$=(277,68+145,4585+93,4731+100,0269) \mathrm{kkal}$

$=616,64 \mathrm{kkal}$

Sedangkan kebutuhan kalori untuk mahasiswi umur 19 perhari $2250 \mathrm{kkal}$, dan laki laki $2725 \mathrm{kkal}$

1. Untuk makan siang kira-kira porsinya $30 \%$,untuk wanita $=0,3 \times 2250 \mathrm{kkal}=675 \mathrm{kkal}$. Dari nasi timbel, goreng ayam, tahu dan tempe harus ditambah $1 / 4$ porsi ( 39,25 gram) sayur kangkung dan minum air minerah untuk memenuhi jumlah makan siangnya sebesar $675 \mathrm{kkal}$.

2. Untuk makan siang kira-kira porsinya $30 \%$,untuk laki-laki $=0,3 \times 2725 \mathrm{kkal}=832,5 \mathrm{kkal}$, makan siangnya menu mie ayam dengan satu buah baso tahu siomay dan air mineral sudah mendapatkan kalori 845,98 kkal.

3. Kesimpulannya menu yang ditawarkan di kantin kampus IV UNPAS, sudah cukup memenuhi kebutuhan asupan makan siang mahasiswa unpas yang berada di jalan setiabudi no. 193 .

Tabel 11. Distribusi Responden Mahasiswa Berdasarkan Kategori Status Gizi

\begin{tabular}{|c|c|c|}
\hline Status Gizi & Frekuensi & Presentase (\%) \\
\hline Kurus Berat & 14 & 20 \\
\hline Kurus Ringan & 3 & 4 \\
\hline Normal & 46 & 66 \\
\hline Gemuk Ringan & 3 & 4 \\
\hline Gemuk Berat & 4 & 6 \\
\hline Total & 70 & 100 \\
\hline
\end{tabular}


Tabel 11. Hubungan Pengetahuan Gizi dan Pola Konsumsi dengan Status Gizi Mahasiswa Teknologi Pangan

\begin{tabular}{|c|c|c|c|}
\hline \multicolumn{5}{|c|}{ Tingkat Pengetahuan } \\
\hline Status Gizi & Baik & Cukup & Kurang \\
\hline Kurus Berat & $2(2,86 \%)$ & $2(2,86 \%)$ & $1(1,43 \%)$ \\
\hline Kurus Ringan & $3(4,29 \%)$ & $8(11,43 \%)$ & $3(4,29 \%)$ \\
\hline Normal & $9(12,86 \%)$ & $23(32,86 \%)$ & $11(15,71 \%)$ \\
\hline Gemuk Ringan & $0(0 \%)$ & $2(2,86 \%)$ & $1(1,43 \%)$ \\
\hline Gemuk Berat & $1(1,43 \%)$ & $2(2,86 \%)$ & $2(2,86 \%)$ \\
\hline \multicolumn{4}{|c|}{ Pola Konsumsi } \\
\hline Status Gizi & Baik & Cukup & Kurang \\
\hline Kurus Berat & $0(0 \%)$ & $1(1,43 \%)$ & $4(5,71 \%)$ \\
\hline Kurus Ringan & $1(1,43 \%)$ & $3(4,29 \%)$ & $10(14,3 \%)$ \\
\hline Normal & $11(15,71 \%)$ & $9(12,86 \%)$ & $25(35,71 \%)$ \\
\hline Gemuk Ringan & $0(0 \%)$ & $0(0 \%)$ & $2(2,86 \%)$ \\
\hline Gemuk Berat & $2(2,86 \%)$ & $0(0 \%)$ & $2(2,86 \%)$ \\
\hline \multicolumn{4}{|c|}{ Raihan Nilai } \\
\hline Status Gizi & Sangat Baik & Baik & Cukup \\
\hline Kurus Berat & $2(2,86 \%)$ & $1(1,43 \%)$ & $0(0 \%)$ \\
\hline Kurus Ringan & $8(11,43 \%)$ & $2(2,86 \%)$ & $0(0 \%)$ \\
\hline \multicolumn{5}{|c|}{ Normal } & $38(54,28 \%)$ & $8(11,43 \%)$ & $0(0 \%)$ \\
\hline Gemuk Ringan & $2(2,86 \%)$ & $1(1,43 \%)$ & $0(0 \%)$ \\
\hline Gemuk Berat & $3(4,29 \%)$ & $1(1,43 \%)$ & $0(0 \%)$ \\
\hline
\end{tabular}

\section{Kesimpulan}

1. Ada hubungan antara pengetahuan gizi dengan status gizi,

2. Ada hubungan antara pola konsumsi dengan status gizi,

3. Ada hubungan antara pengetahuan gizi dan pola konsumsi dengan status gizi pada mahasiswa

4. Ada hubungan antara raihan nilai dengan status gizi, pada mahasiswa Program Studi Teknologi Pangan FT UNPAS

5. Kesimpulannya menu yang ditawarkan di kantin kampus IV UNPAS, sudah cukup memenuhi kebutuhan asupan makan siang mahasiswa UNPAS yang berada di jalan setiabudi no. 193 .

\section{Daftar Pustaka}

1. Almatsier, S. 2003. Prinsip Dasar Ilmu Gizi. Vol. 7. PT. Gramedia Pustaka Utama. Jakarta.

2. Almatsier, S., Soetardjo, S. dan Soekatri, M. 2011. Gizi Seimbang dalam Daur Kehidupan. PT. Gramedia Pustaka Utama. Jakarta.

3. Anggraeni, M. 2000. Pendidikan Gizi Remaja Perkotaan di Daerah Khsuus Ibukota Jakarta. Skripsi. Institut Pertanian Bogor. Bogor.

4. Balitbang Kemenkes RI. 2013. Riset Kesehatan Dasar (RISKESDAS). Balitbang Kemenkes RI. Jakarta.

5. Bhandari, S., Sayami, J.T., Thapa, P., Sayami, M., Kandel, B.P., and Banjara, M.R., 2016. Dietary Intake Patterns and Nutritional Status of
Women of Reproductive Age in Nepal: Findings from a Health Survey. Archives of Public Health. Nepal. 74:2.

6. Camille, A. 2007. Nutrition Knowledge, Attitudes, and Practices of High School Coaches: Implications for Nutrition Education. Iowa State University Ames. Iowa 2: 109-117.

7. Dewi, S.R. 2013. Hubungan antara Pengetahuan Gizi, Sikap Terhadap Gizi, dan Pola Konsumsi Siswa Kelas XII Program Keahlian Jasa Boga di SMKN 6 Yogyakarta. Skripsi. Universitas Negeri Yogyakarta. Yogyakarta..

8. Florence, A. G. 2014. Hubungan Pengetahuan tentang Pencegahan Dismenore dengan Kejadian Dismenore pada Remaja Putri di SMKN 3 Bandung. Tugas Akhir. Politeknik Kesehatan Kemenke. Bandung.

9. Gouado, I. T. E., Zolo, P.H. 2010. Nutritional Status, Food Habits and Energy Profile of Young Adult Cameroonian University Students. African Journal of Food Science 4 (12): 748 - 53.

10. Hockenberry, M., Wilson, D., and Rodgers, C. C. 2017. Essentials of Pediatric Nursing. Elsevier. Missouri.

11. Irawati, D., Fachrurozi. 1992. Penelitian Gizi dan Makanan. Pusat Penelitian dan Pengembangan Gizi. Bogor.

12. Lateef, O.J., Njogu, E., Kiplamai, F., Haruna, U.S., and Lawal, R.A. 2016. Breakfast, Food Consumption Pattern and Nutritional Status of Students in Public Secondary Schools in Kwara State, Nigeria. Asian Network for Scientific Information. Pakistan 15(2): 140-147.

13. Leyna, G.H., Mmbaga, E.J., Mnyika, K.G., Hussain, A., dan Klepp, K.I. 2010. Food Insecurity is Associated with Food Consumption Patterns and Anthropometric Measures but not Serum Micronutrient Levels in Adults in Rural Tanzania. Public Health Nutrition. Tanzania 13(9): 1438-1444.

14. Marita, M.C. 2001. Parent, Peer, and Media Influences on Body Image and Strategies to Both Increase and Decrease Body Size Among Adolescence Boys and Girls. Adolescent Medicine Clinics 36 (142).

15. Notoatmodjo, S. 2007. Promosi Kesehatan dan Ilmu Prilaku. PT. Rineka Cipta. Jakarta.

16. Sayogo, S. 2011. Gizi Remaja Putri. Balai Penerbit Fakultas Kedokteran Universitas Indonesia. Jakarta. 
17. Sebayang, A. N. 2012. Gambaran Pola Konsumsi Makanan Mahasiswa di Universitas Indonesia. Skripsi. Universitas Indonesia. Jakarta.

18. Sediaoetama, A. D. 2000. Ilmu Gizi Untuk Mahasiswa dan Profesi Jilid I. Dian Rakyat. Jakarta.

19. Soekirman. 2000. Ilmu Gizi dan Aplikasinya untuk Keluarga dan Masyarakat. Direktorat Jenderal Pendidikan Tinggi. Departemen Pendidikan Nasional. Jakarta.

20. Soekirman. 2002. Ilmu Gizi dan Aplikasinya. Dirjen Perguruan Tinggi Depdiknas. Jakarta.

21. Soekirman. 2004. Widyakarya Nasional Pangan dan Gizi VIII. LIPI. Jakarta.

22. Suhardjo. 2006. Perencanaan Pangan dan Gizi. Bumi Aksara. Jakarta.

23. Supariasa, I.D.N., Bakri, B., Fajar, I. 2014. Penilaian Status Gizi. Penerbit EGC. Jakarta.

24. Supariasa, I.D.N. 2013. Pendidikan \& Konsultasi Gizi. Penerbit EGC. Jakarta.

25. Swarjana, I.K. 2012. Metodologi Penelitian Kesehatan. CV Andi Offset. Yogyakarta.

26. Spronk, I., Kullen, C., Burdon, C., and O’Connor, H. 2014. Relationship Between Nutrition Knowledge and Dietary Intake. University of Wollongong. Australia 111 (10): 1713-1726.

27. Tombs, A. M. 2009. Eating Patterns and Physical Activity Levels of Adolescents with Differing Weight Status. Thesis. D'Youville College. USA.

28. Widyakarya Nasional Pangan dan Gizi (WKNPG). 1998. Pangan dan Gizi Masa Depan : Meningkatkan Produktifitas dan daya saing Bangsa. LIPI. Jakarta.

29. Windhi. 2006. Masyarakat Indonesia Masih Kurang Pengetahuan Gizi Seimbang.http://www.centroone.com/News/Detail/ 2016/2/6/7040/masyarakat-indonesia-masihkurang-pengetahuan-gizi-seimbang- $[6$ Februari 2016].

30. Wong. 2009. Buku Ajar Pediatrik. Penerbit EGC. Jakarta. 